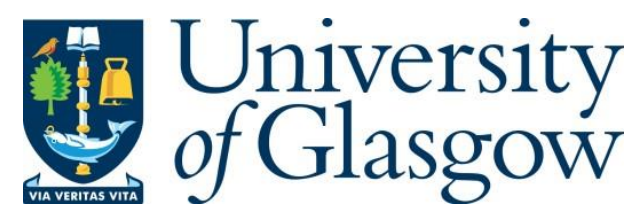

Robbie, J. (2020) John MacAskill, Scotland's Foreshore: Public Rights, Private Rights and the Crown, 1840-2017. Edinburgh Law Review, 24(2), pp. 312-313.

There may be differences between this version and the published version. You are advised to consult the publisher's version if you wish to cite from it.

$\underline{\text { http://eprints.gla.ac.uk/215901/ }}$

Deposited on: 15 May 2020

Enlighten - Research publications by members of the University of Glasgow http://eprints.gla.ac.uk 


\section{John MacAskill, SCOTLAND'S FORESHORE: PUBLIC RIGHTS, PRIVATE RIGHTS AND THE CROWN, 1840-2017}

Edinburgh: Edinburgh University Press (https://euppublishing.com/), 2018. Scotland's Land Series. xi $+260 \mathrm{pp}$.

ISNB 9781474436915. £80.

MacAskill notes in the introduction to this book that it "may seem that the ownership of and management of Scotland's foreshore is an unremarkable subject. But this is far from so..." (2). This claim is consistently verified over the course of this volume, which examines this topic and reveals that the foreshore has been the site of several conflicts generated by broad and controversial issues related to land and its ownership in Scotland. Such issues include the role of the Crown in the promotion of the public interest; the role and value of the protection of private property; the power of those with vested interests in land and their ability to influence the legislative process; the commodification of natural resources; the struggle for land reform and the precarious position of crofters and cottars; as well as the progress towards greater devolution in Scotland.

The foreshore is the area of land between the high and low water marks of the ordinary spring tides. At the beginning of the $19^{\text {th }}$ century, there was a widely held view that the foreshore was owned by adjacent landowners as a pertinent of their lands and the Crown's interest was merely to protect public rights over the foreshore (3). However, from the 1830s onwards, as outlined by MacAskill, the Crown began to challenge this assumption and actively assert claims to ownership of the foreshore. The Association of Seaboard Proprietors was then formed in 1861 in order to dispute these claims and to establish through legislation or case law that landowners owned the foreshore next to their estates. The 130 members of this formidable Association owned between them over $28 \%$ of the total landmass of Scotland (34). These members were motivated by a desire to battle what they perceived as the unjust claims of the Crown and attacks on their rights of private property.

The work of the Association had multiple consequences, many of which are still evident today. MacAskill shows that the Association and its lawyers, Skene \& Peacock, influenced amendments of the Crown Lands Bill in the House of Lords in 1866, which resulted in the continuation of the requirement to obtain full value for sales and leases of the Crown-owned foreshore under the management of the Board of Trade (ch 3). This was much to the consternation of Thomas Farrer, permanent secretary of the Board of Trade at this time, who believed in a strong role for the Crown as defender of the public interest in relation to foreshore and who felt the obligation to obtain full value limited the discharge of this function. Following devolution of management of the Scottish Crown Estate assets in 2017 to the Scottish Ministers, the Crown-owned foreshore in Scotland is now managed by Crown Estate Scotland. Nevertheless, the $19^{\text {th }}$ century amendments have a living legacy in the new legislation which is being implemented to govern the Scottish Crown Estate. Under s11 of the Scottish Crown Estate Act 2019 (not yet in force), the manager of the Scottish Crown Estate assets, which includes the foreshore, must obtain market value for sales and leases of the assets. However, this duty is mitigated by additional modern provisions that allow transactions for less than market value in order to promote inter alia social and environmental wellbeing or sustainable development.

MacAskill also traces the background and decision of the important case of Agnew $v$ Lord Advocate (1873) 11 M 309. This case was specifically chosen as favourable for the Association to support. The Inner House of the Court of Session, however, struck a compromise between the competing views of the Crown and the adjacent landowners, finding that the foreshore was not inter regalia as to ownership but belonged to the Crown originally, like all other land. It was decided there was no need for an express grant to prove transfer of the foreshore and possession of the foreshore could be important with regards to either explaining the extent of a grant of land (which could be deemed to include the foreshore) or in order to acquire the foreshore through prescription. Agnew settled the law on this question and, with the history of the kelp industry in Scotland, it is possible that much of the foreshore has been transferred into private hands. MacAskill remarks that it is with great irony that in spite of their own insecure situation, the efforts of crofters and cottars in the kelp industry 
had a role in securing the title to the foreshore for adjacent landowners (12-13 and ch 8). Again, this has modern implications. As hinted to by MacAskill, it is difficult to see how ownership of the foreshore can be determined within the project of the completion of the Land Register by 2024, without a detailed investigation of numerous titles and historic acts of possession (2).

This is a rich volume. MacAskill has been meticulous in his research and the result is a fascinating guide to the history of the controversies regarding the ownership and management of this valuable natural resource. Throughout the book, MacAskill is careful to trace the contours of the fault line which runs through the saga of the disputes; this being the importance of managing the foreshore in the public interest and how such management has been constrained due to focus on the monetary value of the asset. In light of the ongoing challenges facing the management of our natural resources and the importance of the foreshore in relation to societal needs and development as well with regards to environmental protection and climate change mitigation, I can only endorse the view of MacAskill and Farrer that ownership and management of the foreshore should not become simply "a matter of $£$. s. d." (envoi). 